first-class honours degree in civil engineering at the University of Manchester in 1935, he joined the design department of Armstrong Whitworth the same year. He was initially engaged on the development of stress analysis methods for monocoque fuselages and box spar wings in connexion with the design of the Ensing. Later, as head of a special research and development section, he was concerned, among other things, with boundary layer suction, the aero-elastic characteristics of tailless aircraft, gust alleviating devices, and the economics of turbojet aircraft.

In 1947 he joined the Flutter and Vibration Division of the Royal Aircraft Establishment as a principal scientific officer in charge of the theoretical section. In this capacity he took active measures to encourage the aircraft industry to undertalke its own flutter investigations, and eventually to increase the scope of flutter work generally. In 1950 he was appointed head of the Livision, and continued to lead activities in the aircraft flutter field, notably in the direction of model testing and full-scale flight flutter testing, and in the application of high-speed computors to theoretical flutter investigations. $\mathrm{Mr}$ Templeton is the author of a Royal Aeronautical Society monograph on "Mass Balancing of Aircraft Control Surfaces" and he is a fellow of that Society. In July 1956 he was appointed assistant director of Civil Aircraft Research and Development at the Ministry of Supply.

\section{Royal Aeronautical Society}

Honorary fellowship of the Royal Aeronautical Society has been accepted by H.R.H. Prince Bernhard of the Netherlands. Miss B. Voyce, an exmember of the staff, has been appointed an honorary companion of the Society. The following awards have been made by the Society : The Society's Gold Medal to Prof. J. C. Hunsaker, for his contributions to aeronautical research and education, including his inspired chairmanship of the National Advisory Committee for Aeronautics, whose work has so greatly benefited aeronautical activities everywhere (this is the highest honour which the Society can confer for work of an outstanding nature in aeronautics); The Society's Silver Medal to Mr. M. B. Morgan, for his contributions in the execution and direction of aeronautical research and development; The Society's Bronze Medal to Mr. F. B. Greatrex, for his work on the reduction of noise from aeroengines; The British Gold Medal for Aeronautics to Mr. R. L. Lickley, for his outstanding practical contributions to aircraft design and development; The British Silver Medal for Aeronautics to Mr. Charles Abell, for his engineering achievements contributing to efficiency in airline operations ; Wakefield Gold Medal to Mr. Caradoc Williams, for his contributions to the development and use of radio aids to navigation ; R.P. Alston Memorial Medal to Mr. Bernard Lynch, for his practical achievement in the flight testing of ejector seats; George Taylor (Australia) Gold Medal to Mr. G. Forrest and Mr. K. Gunn, for their paper on problems associated with the production and use of wrought aluminium alloys; The Simms Medal to Mr. E. G. Broadbent, for his paper on aeroelastic problems in connexion with high-speed flight; The Edward Busk Memorial Prize to Mr. I. M. Davidson, for his paper on the jet flap; The Orville Wright Prize to Dr. B. S. Stratford, for his papers on the jet flap published in the Aeronautical
Quarterly; The Herbert Akroyd Stuart Memorial Prize to Dr. J. S. Clarke, for his review of some combustion problems associated with the aero gas turbine; The Branch Prize to Mr. E. R. Major, for his paper on some maintenance aspects of Viscount operation; The Navigation Prize to Mr. R. A. Burberry, for his paper on aerial systems for aircraft ; and The Usborne Memorial Prize to Mr. T. M. Corson, for his paper on the propeller-turbine in airline service.

\section{U.K. Atomic Energy Authority: Safety Execu- tive Committee}

The Atomic Energy Authority Act, 1954, places on the Atomic Energy Authority the duty of securing that no ionizing radiation from any of its premises or from any waste discharged from its premises shall cause any hurt to any person or damage to any property. The Authority has carried out these responsibilities through a number of committees dealing with the various aspects of safety policy. These bodies have now been re-organized into two main committees which will be served by a newly formed Safety Branch. The functions of the Safety Executive Committee are to consider the safety policy of the Authority in the design, siting and operation of reactors, process plants and laboratory installations, using the standards recommended by the Health Advisory Committee (see below); to approve, for issue by the Authority, general codes of practice in such matters; and to refer to the Reactor Safety Research Committee such items as they consider should be the subject of basic research.

This Committee is served by two sub-committees, namely, the Reactor Safety Committee, which has absorbed the Reactor Location and Reactor Operation Panels of the old Project Health Committee; and the Ancillary Establishments Safety Committee, which covers all plants and experimental facilities other than reactors. There is also an independent Reactor Research Committee, one of the functions of which is to advise on the technical suitability of sites proposed for nuclear facilities of all sorts, including nuclear power stations.

Health Advisory Committee

The Health Advisory Committee is composed of the chief medical officers and the chief health physicists of the Authority and the Authority's consultants. The functions of this Committee are to consider, and advise the Authority on, the effects on public and occupational health and safety of the atomic energy programme; and to identify research problems on which work is required in relation to the control of health hazards in the development of atomic energy. This Committee also defines standards of occupational and non-occupational exposure to radiation and radioactive substancos and passes these standards to the Safety Executive Committee for application.

The newly formed Safety Branch will meet the Authority's need for a permanent staff to serve this Committee structure and will operate from the head. quarters of the Industrial Group at Risley. It will provide the focus for consideration not only of the Authority's own proposals but also of industrial proposals put to it either directly or through Government departments. It will service the main committees and sub-committees and will furnish the 